\title{
Musculoskeletal Injuries in the Military Staff: A Systematic Review
}

\section{ART ICLE INF O}

\section{Article Type}

Systematic Review

\section{Authors}

Behrouz H. ${ }^{1} M S c$,

Malekifar E. ${ }^{1} M S c$,

Bahrami R. ${ }^{1} M S C$,

Fathinia T. ${ }^{1} M S c$,

Mahmoudi H. ${ }^{* 2} P h D$

How to cite this article
Behrouz H, Malekifar E, Bahrami
R, Fathinia T, Mahmoudi H. Muscu-
loskeletal Injuries in the Military
Staff: A Systematic Review. Iranian
Journal of War \& Public Health.
2020;12(3):197-205.

\section{A B S T R A C T}

Aims Musculoskeletal disorders are common among military personnel and can have a negative impact on their missions. Therefore, this study aimed to investigate the prevalence and type of musculoskeletal disorders in the military.

Instruments \& Methods This study aimed to investigate diseases of the musculoskeletal disorders common among the military to review systematically. International Information PubMed, ScienceDirect, and Google Scholar and the base of internal SID, Magiran and the Bank of the Medical Sciences journal of the country searched for two languages, English and Persian, from 2000 to June 2020.

Findings Factors such as gender, age, type of workforce, and whether or not training and standardization are influencing these injuries. Muscle and skeletal injuries are among the most important problems in the military, which reduces their readiness and prevents them from serving. Common areas of injury include the lower limbs, back, upper limbs, and shoulders. Irreparable factors such as gender, race, ethnicity, and modifiable factors such as physical fitness, medication use, and dietary habits, can be involved.

Conclusion The incidence of musculoskeletal disorders among military personnel is inevitable. Therefore, it is necessary to try to deal with the effects of these injuries quickly, which requires careful planning and identification of the causes and grounds for these injuries.

Keywords Military; Injury; Musculoskeletal
${ }^{1}$ Critical Care Nursing Department, Nursing Faculty, Baqiyatallah University of Medical Sciences, Tehran, Iran

"'Trauma Research Center" and "Department of Medical-Surgical, School of Nursing", Baqiyatallah University of Medical Sciences, Tehran, Iran

\section{*Correspondence}

Address: Trauma Research Center, Baqiyatallah University of Medical Sciences, Mollasadra Street, Tehran, Iran.

Phone: +98 (21) 87555493

Fax: +98 (21) 87550047

h.mahmoudi@bmsu.ac.ir

\section{Article History}

Received: September 16, 2020

Accepted: November 28, 2020

ePublished: March 03, 2021

\section{I T A T I O N L I N K S}

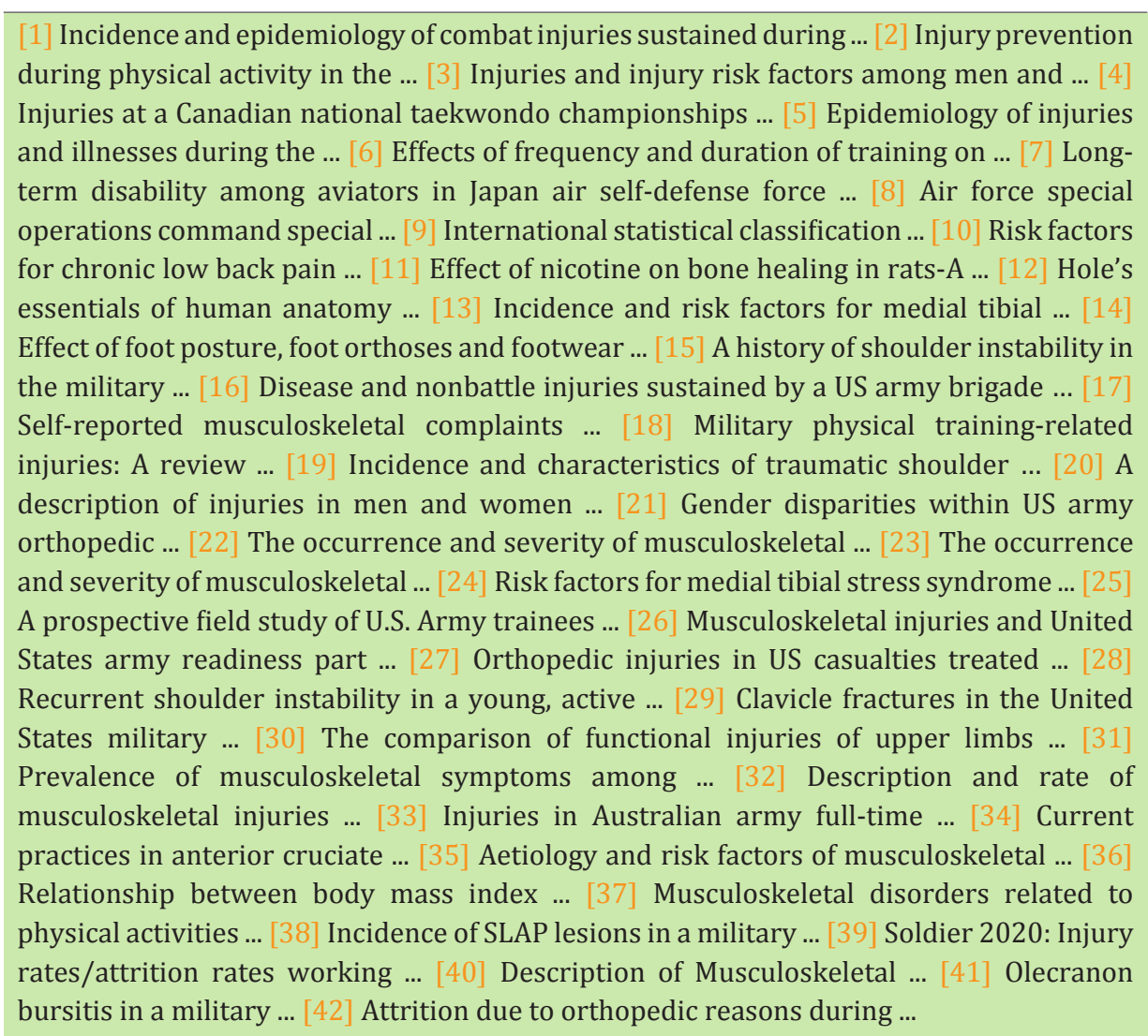


شغلىشان هميشه بايد در بالاترين سطح آمادگى جسمانى و روانى

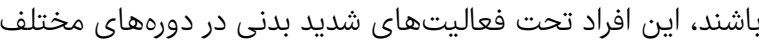

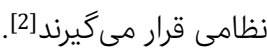

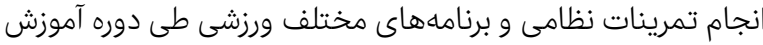

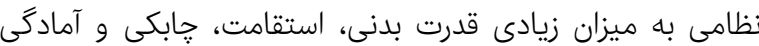

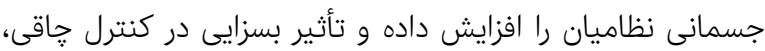

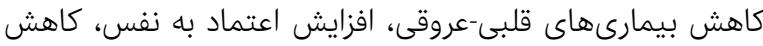

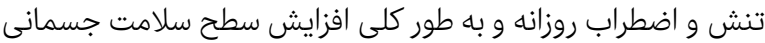

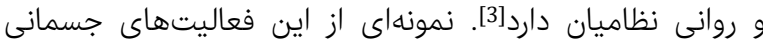
شامل تمرينات نظامى، ورزشهاى آمادگى جسمانى، رزمهاى نئى انفرادى، رزه، بدنسازى و غيره است. تمرينات فيزيكى حين دئ دورهات آموزش نظامى، علاوه بر داشتن منافع براى كاركنان نظامى، ممكن است باعث بروز يكسرى آسيبها شود [4] ناست. صدمات ناشى از آموزش بدنى عضلانى و اسكلتى يك مشكل عمده

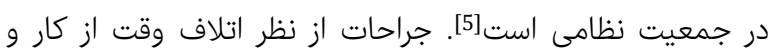
آموزش و كاهش آمادگى نظامى بسيار مهم هستند [6]. بيامدهاى

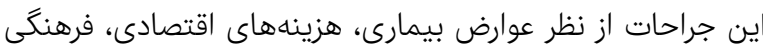

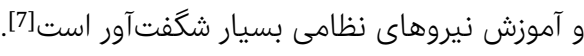

آسيبهاى فيزيكى، نه تنها تاثير شديدى بر ميزان توانايى و آمادگى آنى رزمى نيروهاى نظامى در انجام ماموريتهاى آنى آنها دارد [8]؛ بلكه

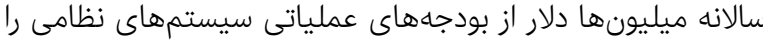

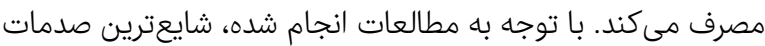
ناشى از انجام تمرينات فيزيكى بهوجودآمدن مشكلات اسكلتى-

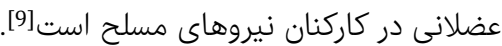

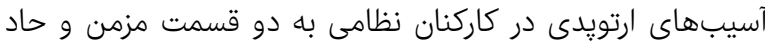
تقسيم مىشوند. آسيبهاى مزمن ماركنان مانند آنتروز دو و بورسيت هستند

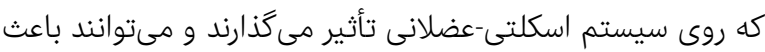

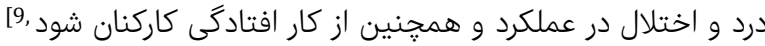

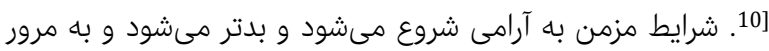

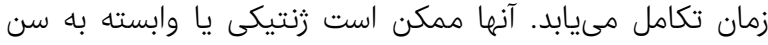

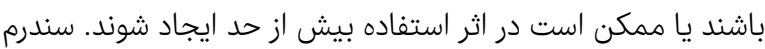

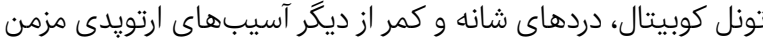

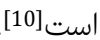
بر خلاف آسيبهاى مزمن، آسيبهاى حاد و ناكمانى ارتويدى مهمترين علت دركيرى يزشكى بين كاركنان نظامى است. ميزان إنى

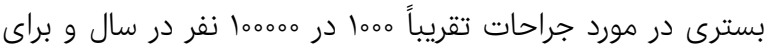

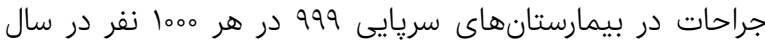

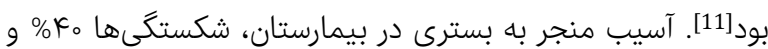

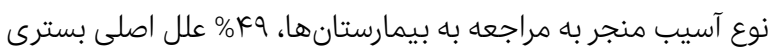

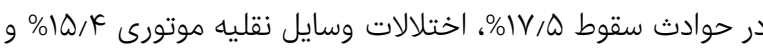

$$
\text { ورزش اسرام بود [12]. }
$$

در ارتش ايلات متحده سلانه بيش از مــهزار سرباز وظيفه ارتش

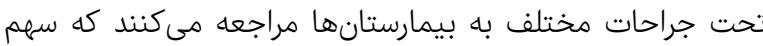

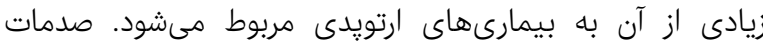

آسيبهاى اسكلتى-عضلانى رايج در نظاميان: يك

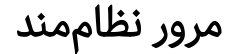

\section{حامد بهروز حكc}

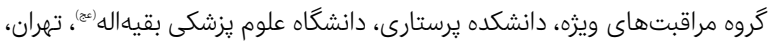

MSc اسماعيل مالكىفر

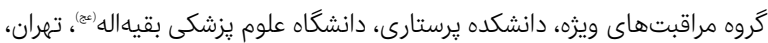

رضا بهرامى MSc

كَروه مراقبتهاى ويزّه، دانشكده يرستارى، دانشكاه علوم يزشكى بقيهاله (ع)، تهران،

MSc طليعه فتحىنيان

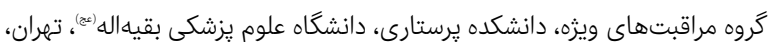
ايران

حسين محمودى " PhD "مركز تحقيقات تروما" و "گروه داخلى-جراحى، دانشكده بِرستارى"، دانشكاه علوم

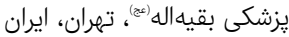

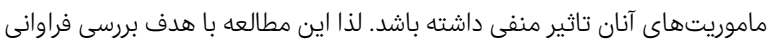

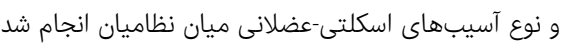

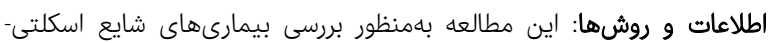
عضلانى ميان نظاميان به صورت مرور سيستماتيك انجام شد. در بإيكاههاى براي اطلاعاتى بينالمللى PubMed، ScienceDirect و و و و

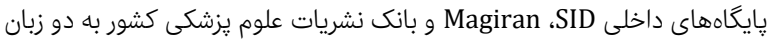

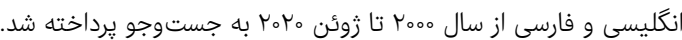

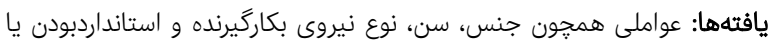

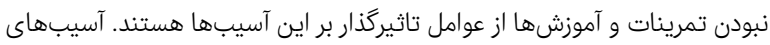

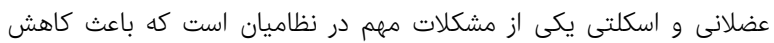

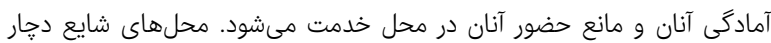

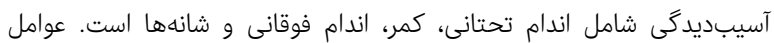

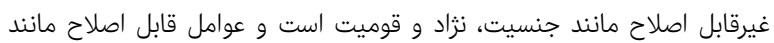

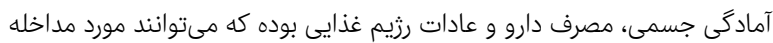

قرار گيرند. نتيجه گيرى: بروز آسيبهاى اسكلتى-عضلانى ميان نظاميان امرى اجتنابنايذير

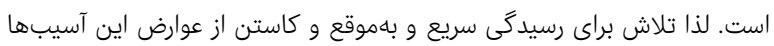

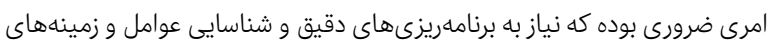

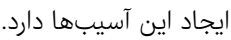

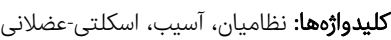

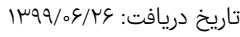

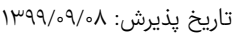
'نويسنده مسئول: h.mahmoudi@bmsu.ac.ir

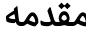

نيروى انسانى، مهمترين سرمايه هر سازمان به خصوص نهادهاى

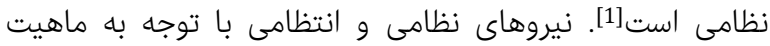


و مقالات نهايى براى ورود به مطالعه انتخاب شدند. در درائ دراين مرحله

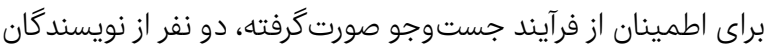

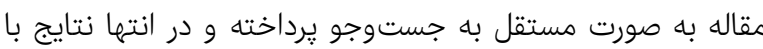
يكديكر مقايسه شد كه در اكثر موارد انطباق داشته و در در موارد

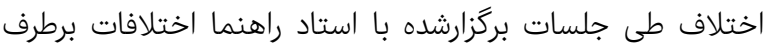

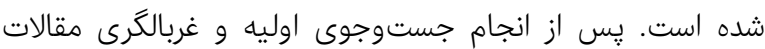
براساس عنوان و بررسى خلاصه و اصل مقالات، ارزيابى و تحليل

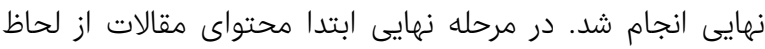

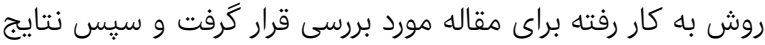

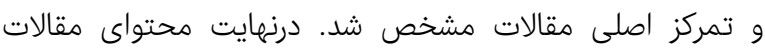

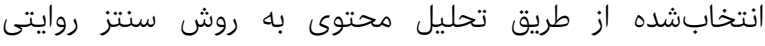
(Narrative Synthesis)

\section{يافتهها} از צ پايكاه اطلاعاتى، مقالات مرتبط با بيمارىهاى شايع اسكلتى-

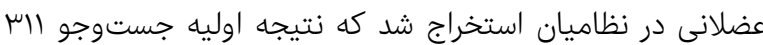

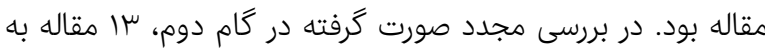

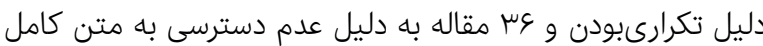

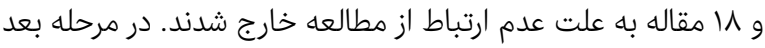

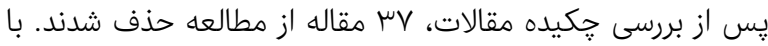

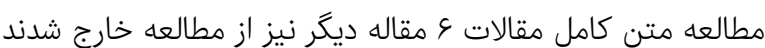
و در نهايت ال مقاله براى بررسى نهايى انتخاب شداند.

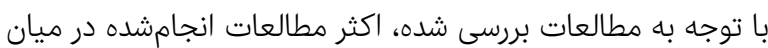

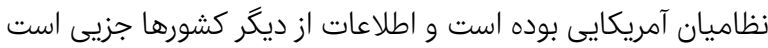

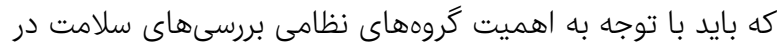

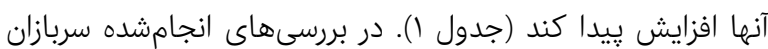
زن نسبت به سربازان مرد از آسيبيذيرى بالاترى در سيستم

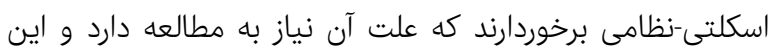

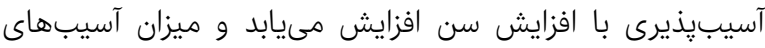

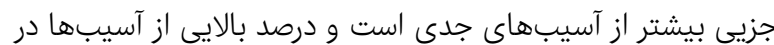

$$
\text { دوران خدمت رخ مىدهد. }
$$

در بررسى جزيىتر مطالعات محلهاى شايع دهار آسيبديدگى

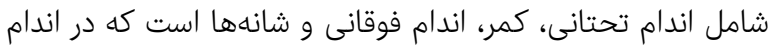

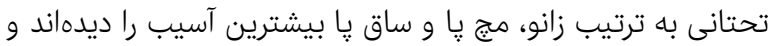
بيشترين دلايل اين اختلالات شامل شكستخى بـانها، صدمات استرس

$$
\text { استخوانى و دررفتخىها است (نمودار (). }
$$

اسكلتى-عضلانى و اسكلتى ॰ه\% از كليه صدمات ناشى از بيمارى و

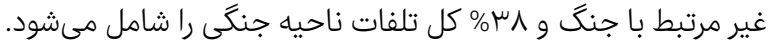
نظارت بر آسيبديدگى، اولين و مهمترين مرحله از روند يِيشكيرى

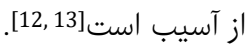

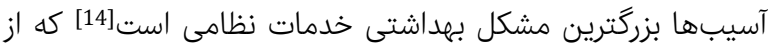

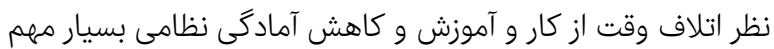

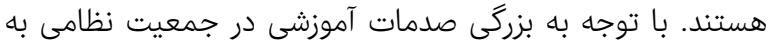

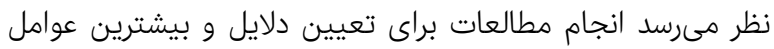

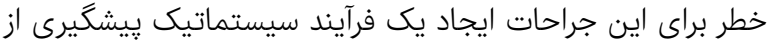

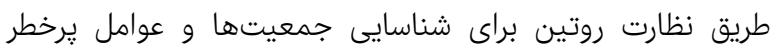

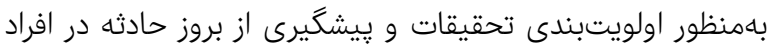

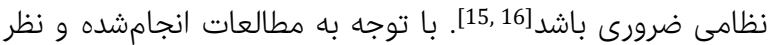

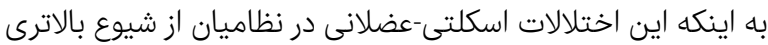

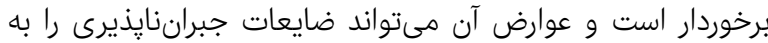

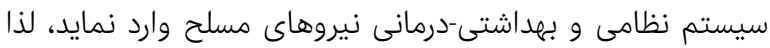
اين مطالعه با هدف بررسى فراوانى و نوع آسيبهاى اسكلتى عضلانى ميان نظاميان انجام شد.

\section{اطلاعات و روشها - (اطلا} اين مطالعه بهمنظور بررسى بيمارىهاى شايع اسكلتى-عضلانى ميان نظاميان به صورت مرور سيستماتيك انجام شده است.

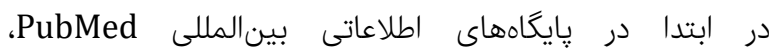
و و ScienceDirect Magiran

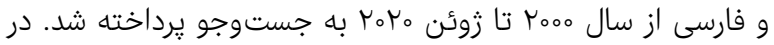

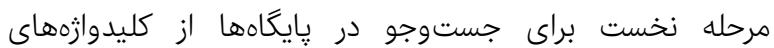
،Orthopedic Surgery ،Musculoskeletal Diseases Military و Orthopedic Procedures شامل بيمارىهاى عضلانى-استخوانى، جراحىهاى ارتويدى و

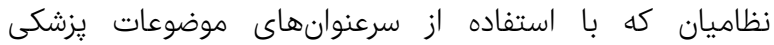
(MeSH)

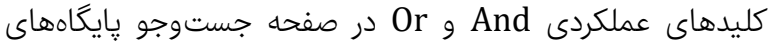

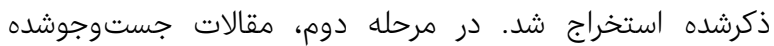

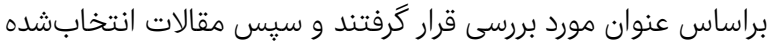

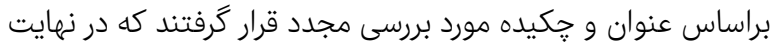

\begin{tabular}{|c|c|c|c|c|c|}
\hline نتايج & متغيرهاى مورد مطالعه & نوع مطالعه & كشور، محيط و نمونه & نويسنده (سال) & مرجع \\
\hline 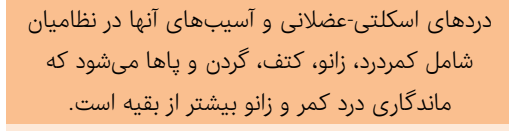 & شيوع و محصل صدمات اسكلتى-عضلانى، سن، & مقطعى & سوئد، Mro سرباز & $\begin{array}{c}\text { هالوارسون و همكاران } \\
\text { (Y.人) }\end{array}$ & [17] \\
\hline 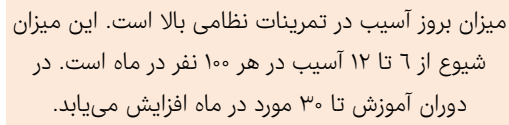 & ميزان شيوع آسيبها، نوع آسيب، محل بروز & مقاله مرورى & ايران، ץ" مقاله & زارعى و رحيمى (عسا) & [18] \\
\hline
\end{tabular}
مقالات باقيمانده براساس متن كامل مورد ارزيابى نهايى قرار كرفتند 


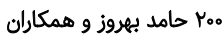

ادامه جدول () نتايج متغيرهاى مورد بررسى در مستندات انتخابى مطالعه

\begin{tabular}{|c|c|c|c|c|c|}
\hline نتايج & متغيرهاى مورد مطالعه & نوع مطالعه & كشور، محيط و نمونه & نويسنده (سال) & مرجع \\
\hline ميزان بروز دررفتخى كتف در ميان نظاميان زاين ها مورد & 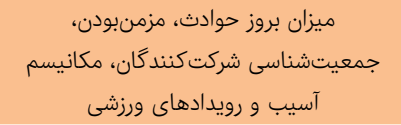 & همكروهى آيندهنكر & 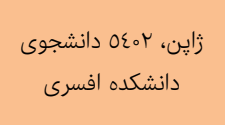 & $\begin{array}{c}\text { آماكو و همكاران } \\
\left(r_{0} / 7\right)\end{array}$ & [19] \\
\hline زنان نظامى نسبت به مردان در معرض آسيبهاى & آسيبهاي اسكلتى-عضلانى، جنس & كذشتهنكر & 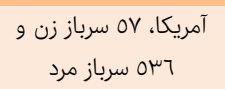 & روى و همكاران (ro10) & [20] \\
\hline 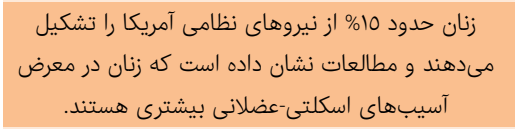 & 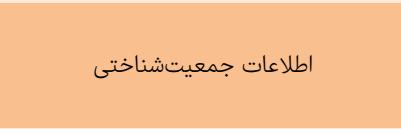 & توصيفى & آمريكا، ror نظامى & 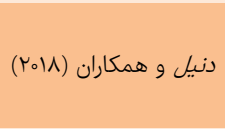 & [21] \\
\hline 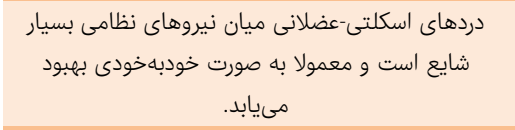 & ارزيابى وقوع، محل و شدت اختلالات & توصيفى & سوئد، 0عـ سرباز & كلد و همكاران (r/r) & [22] \\
\hline 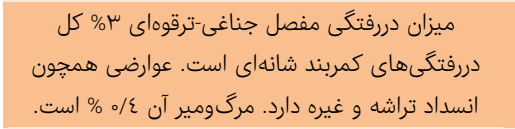 & سن، رتبه و شاخه نظامى & كذشتهنكر & 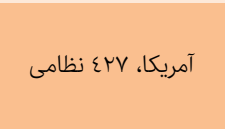 & 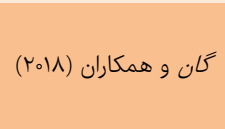 & [23] \\
\hline 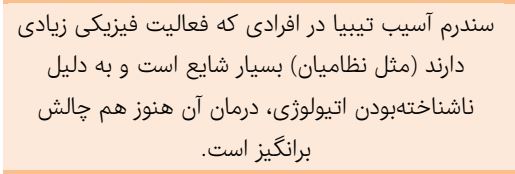 & شركت كنندحًان، جمعيق، مدت مطالعه، انتخاب تشخيص و عوامل & مرورى & آمريكا، آ مقاله & همسترا-رايت و بلوين & [24] \\
\hline 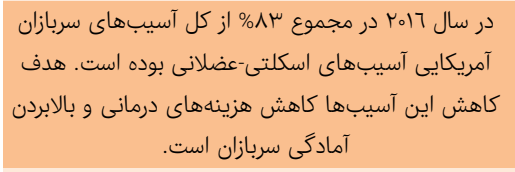 & 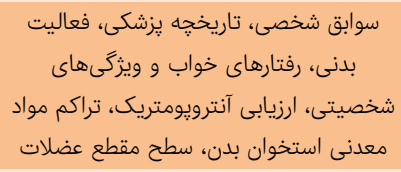 & آيندهنكر & آمريكا، آمهـ كارآموز & $\begin{array}{c}\text { هيوز و همكاران } \\
\text { (r.19) }\end{array}$ & [25] \\
\hline 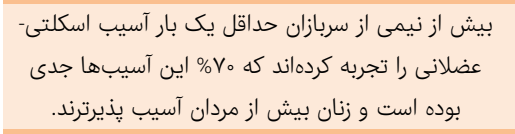 & صدمات اسكلتى-عضلانى، سن، جنس & مرورى & 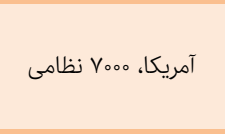 & $\begin{array}{c}\text { ملوى و همكاران } \\
\left(r_{0} r_{0}\right)\end{array}$ & [26] \\
\hline 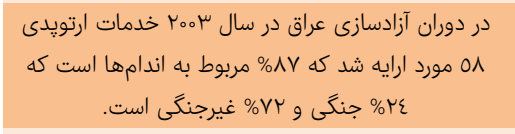 & سن، نوع شكستكى، محل شكستخى، علل & كذشتهنكر & آمريكا، ل م مورد & اناد و هدريك (roم) & [27] \\
\hline دررفتگى كتف حتى بعد از جراحى نيز در عس\% بيماران & دررفتگى شانه، سن، جنس، نوع ترميم قبلى، ورزش قبلى و نوع ورزش در آكادمى & كذشتهنكر & آمريكا، 09 بيمار نظامى & 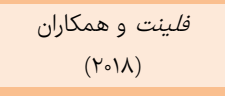 & [28] \\
\hline شكستكى استخوان ترقوه ميان نظاميان آمريكا تقريبا ا & شيوع شكستخىهاى كلاويكل، جنس، نزاد، & كَشتهنگ & 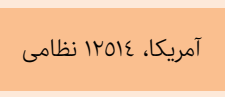 & 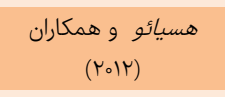 & [29] \\
\hline 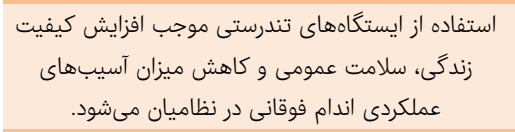 & آسيبهاى اندام فوقانى،كيفيت زندگى، & توصيفى-مقطعى & ايران، مrا نفر مرد عضو & علىدوست و همكاران & [30] \\
\hline 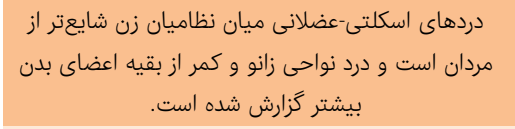 & اختلالات اسكلتى-عضلانى، جنس، سال & توصيفى-مقطعى & برزيل، دانشكه دانشجوى افسرى & لوبز و همكاران (YolV) & [31] \\
\hline 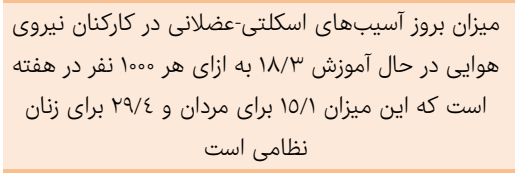 & صدمات اسكلتى-عضلانى، جنس & توصيفى-مقطعى & 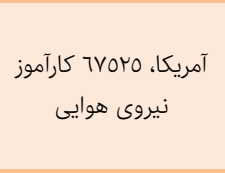 & ناى و همكاران (T-17) & [32] \\
\hline 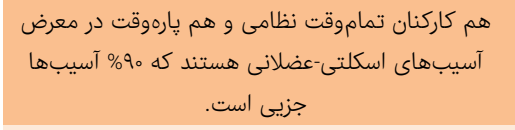 & صدمات اسكلتى-عضلانى، كاركنان تماموقت & كذشتهنكر & استراليا، میرسا نظامى & شرام و همكاران (Y.19) & [33] \\
\hline 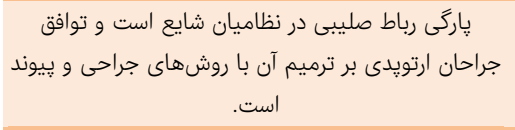 & سن، جنس، روش جراحى & توصيفى & آمريكا، Vo جراح نظامى & $\begin{array}{c}\text { ساينووى و همكاران } \\
\left(r_{0} \mid \Lambda\right)\end{array}$ & [34] \\
\hline 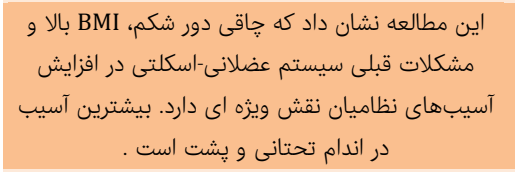 & اختلالات اسكلتى-عضلانى، BMI & توصيفى & فنلاند، ع ج سرباز مرد & تانيلا و همكاران (rolo) & [35] \\
\hline شاخص توده بدنى بر اختلالات اسكلتى-عضلانى و & $\begin{array}{c}\text { اختلالات اسكلتى-عضلانى، وضعيت سلامت } 2 \text { عمومى، شاخص توده بدنى }\end{array}$ & مقطعى توصيفى & ايران، Vo فرد نظامى & 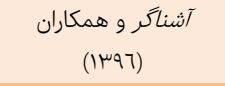 & [36] \\
\hline استفاده از كفىهاى داخل كفش براى سربازان مد نظر قرار & فعاليتهاى جسمانى دوره آموزشى خدمت آسيبهاى اسكلتى-عضلانى شايع & مرورى & ايران، rV مقاله & 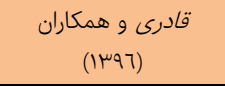 & [37] \\
\hline
\end{tabular}


درد زانوها و ستون فقرات قادر به دويدن، راهييمايى، يرش ازئي وسيله

نقليه و حمل كوله يشتى نيستند.

در فنلاند اختلالات اسكلتى-عضلانى درد كمر (MSD) (77\%)

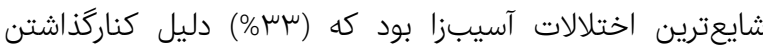

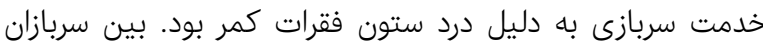

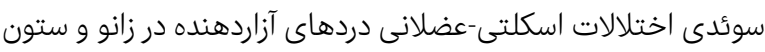

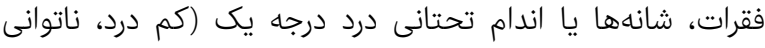

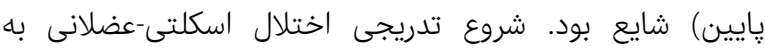

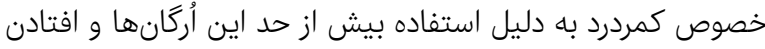

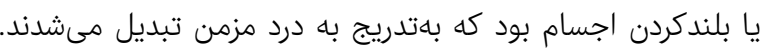

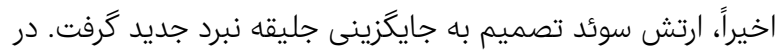

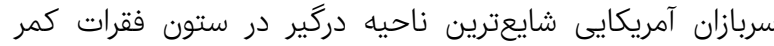

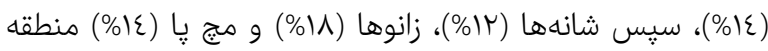

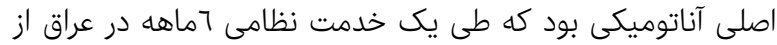

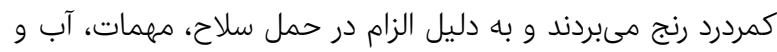
ساير وسايل ضرورى، تجهيزات سنكين بيشتر از معكيلوكرئرم، كوله

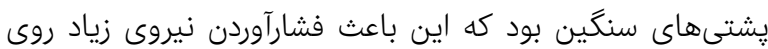

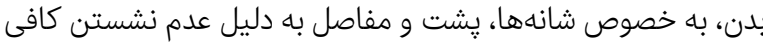

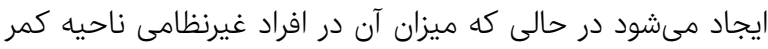

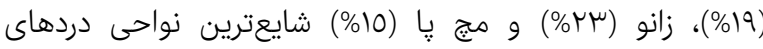

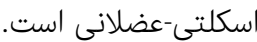

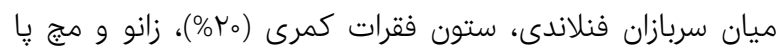
شايعترين دردهاى اسكلتى-عضلانى بود. استرسورها شامل جدائ آنايى

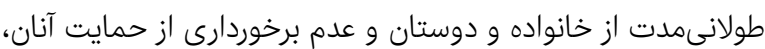

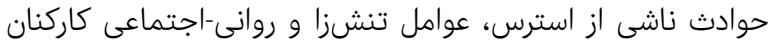

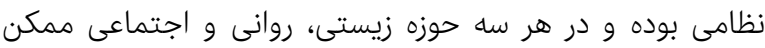
است علت نسبتاً زياد كمردرد بين نظاميان باشد.

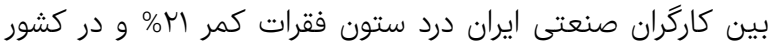

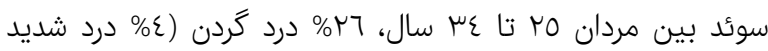

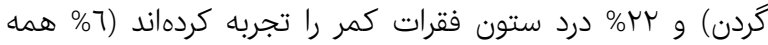

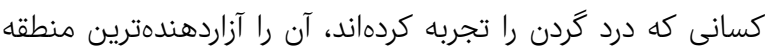

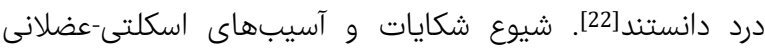
MSCI

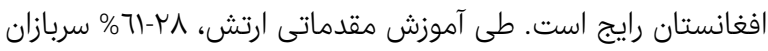

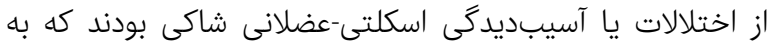

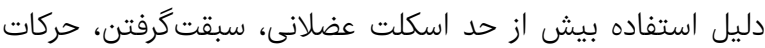

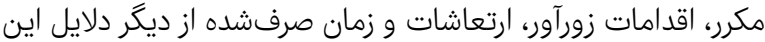

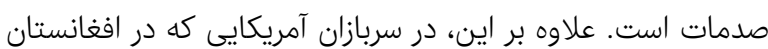

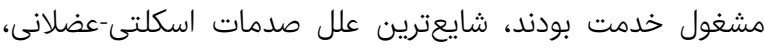

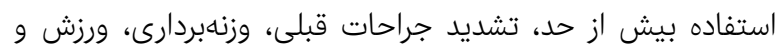

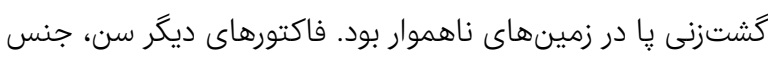

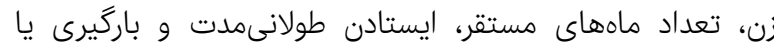

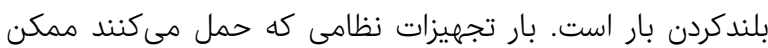
است بيش از حد تحمل فيزيولوزيكى بافتها باشد و بارئ بر توانانيى كار

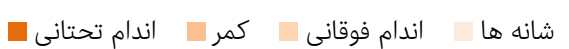

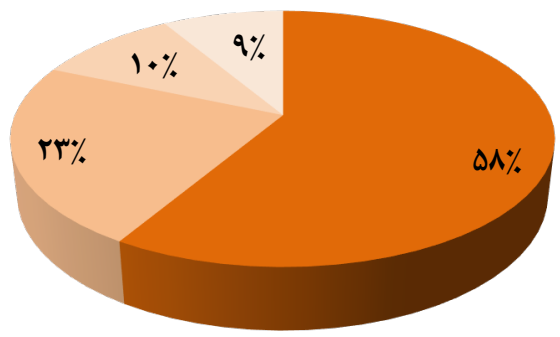

نمودار () محلهاى شايع آسيبديدگى نظاميان در تروما

بحث

در اين مطالعه با استفاده از مرور مقالات منتشرشده، با مقاله

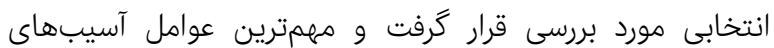

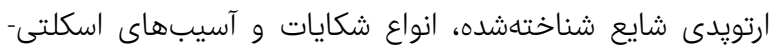
عضلانى (MSCI) در نظاميان مرد و زن، ورزشكاران است [17] و بـانه دليل خصوصيات عوامل خطر ذاتى يا عوامل خطر داخل دانل سازمانى

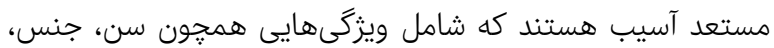

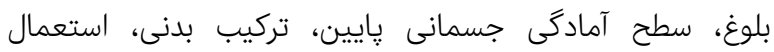

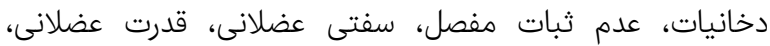

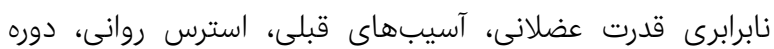

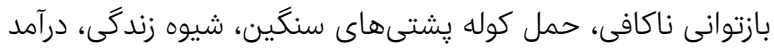

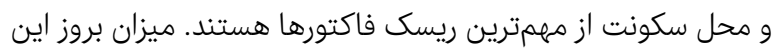

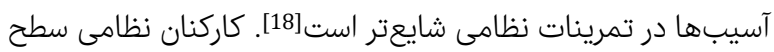

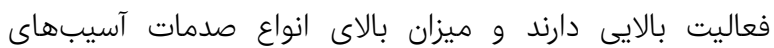

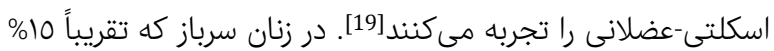
از ارتش فعال ايالات متحده را تشكيل مىدهند و ونسبت به به سربازان

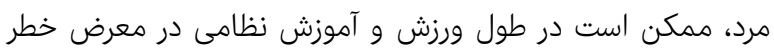

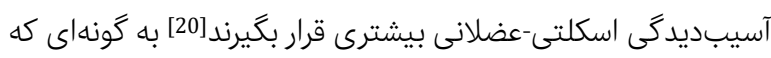

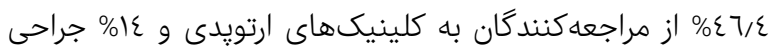

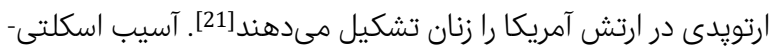

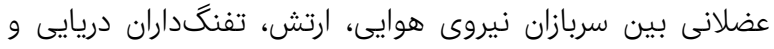

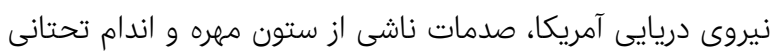

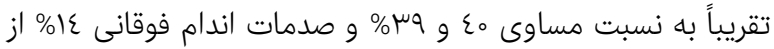

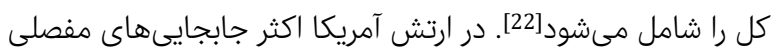

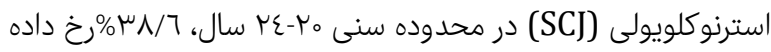

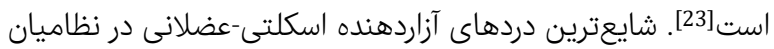

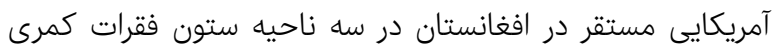

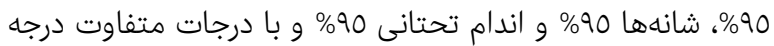

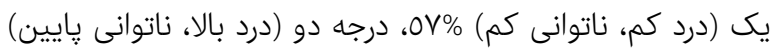

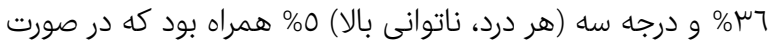

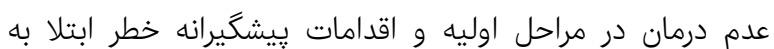

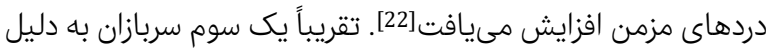


مدمات غيرنظامى (جراحات) سلامت سربازان ارتش آمريكا را تهديد

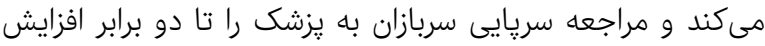

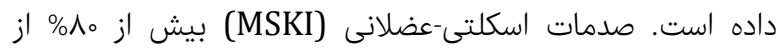

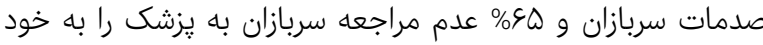
اختصاص داده است. جلوكيرى از بروز خطر و ورزش هرانهاى استاندارد

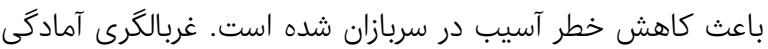

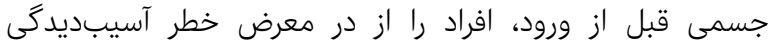

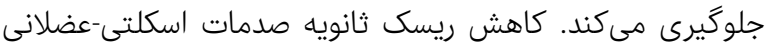
توسط مربيان ورزشى به همراه مراقبتهاى اوليه در واحدهاى

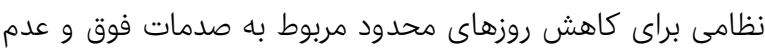

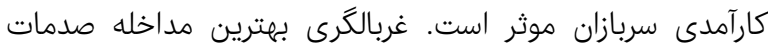

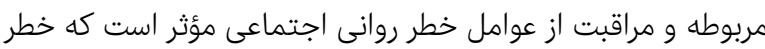

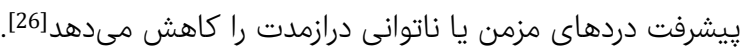

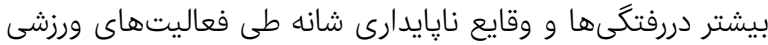

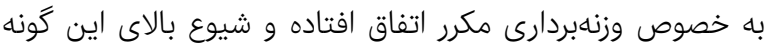

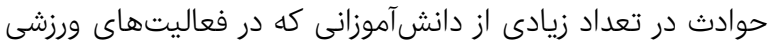

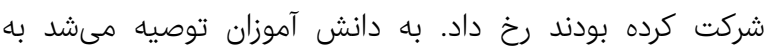

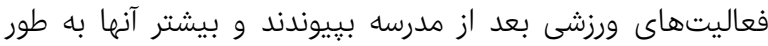

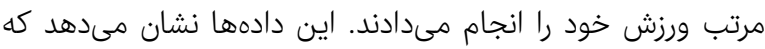

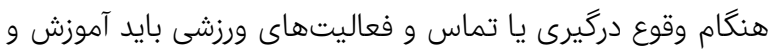

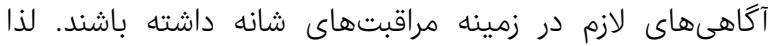

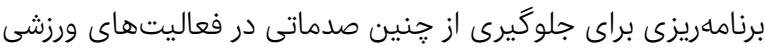

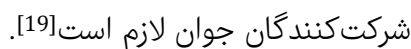

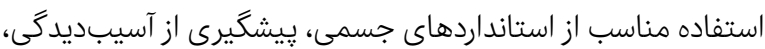

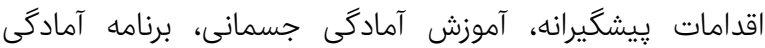
جسمانى متعادل، تمرينات سرعت بالا، كاهش مسافت يِيمودهشده، مسافت طىشده توسط گروههاى توانمندى، بهداشت رئت رفتارى، اتخاذ مفاهيم خواب، فعاليت، تغذيه، اصلاح كمخونى، باعث كاهن كاهش

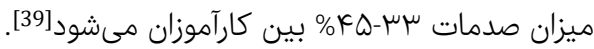
جاقى يك عامل خطر شغلى در ارتباط با ايجاد شكستكى در سربازان

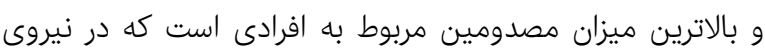

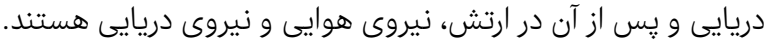

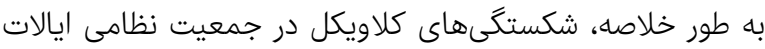

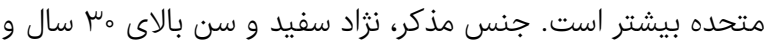
شغل (خدمات، رتبه) و مصرف مشروبات الكلى با بالاترين ميزان

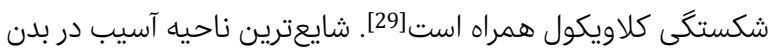

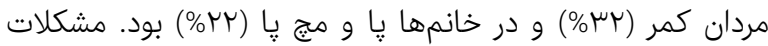

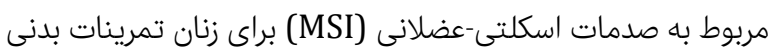
( مسافت زياد و حمل اشياى سنكَين باعث افزايش خطر آسيب درد درد

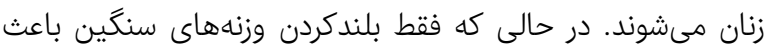

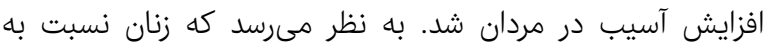
همتايان مرد خود تحمل كمترى در خصوص كارهاى طاقتفرسا
سربازان تأثير كذاشته و در درازمدت بهانه درد مزمن منجر شود. كمر و

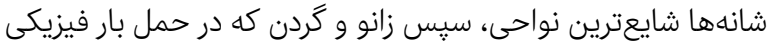

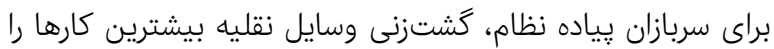

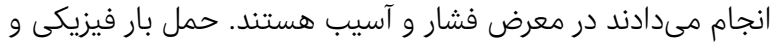

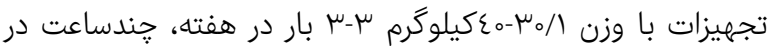

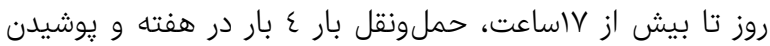

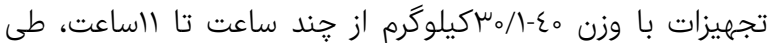

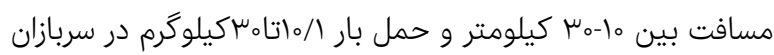

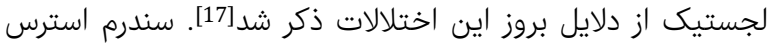

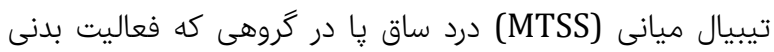

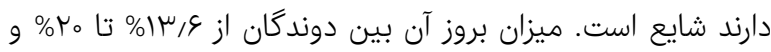

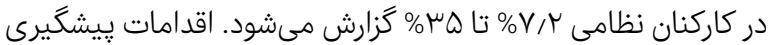

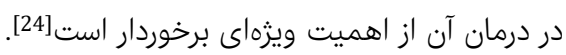

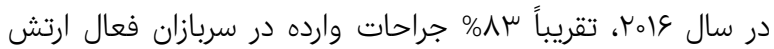

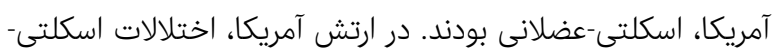

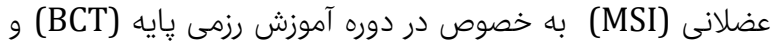
زمان افزايش تمرينات بدنى در ابتداى دوران سربازى شايع استان.

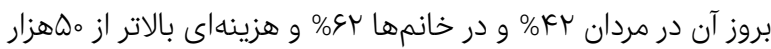

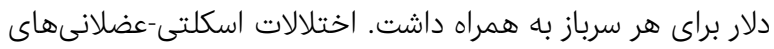

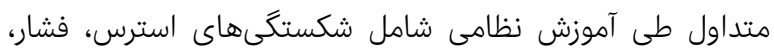

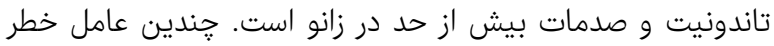

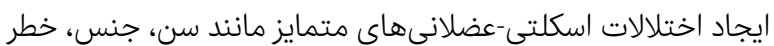

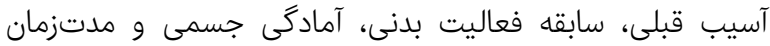
مصرف سيكار است. عوامل خطرناك ديكر مانند استفاده از مسكنها

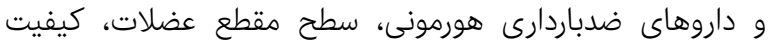

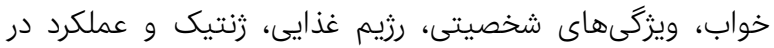

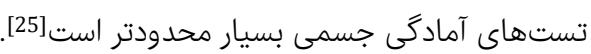
ضايعات يارگى لابروم قدامى و خلفى (SLAP) كه باعث درد شانه

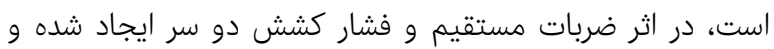

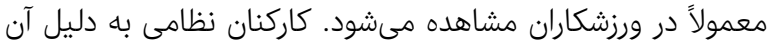

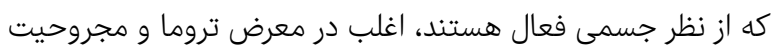

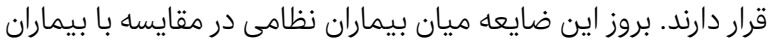

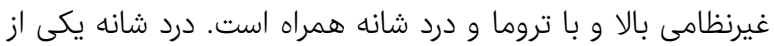

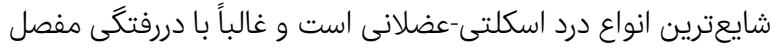

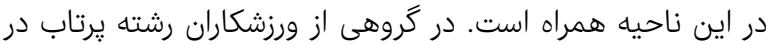

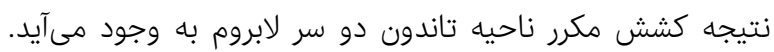

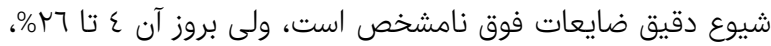
كه 7\% از آنها شايعترين موارد در بيماران تحت آرترن آنروسكويى شانه

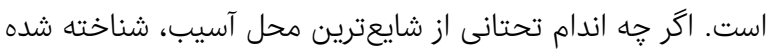

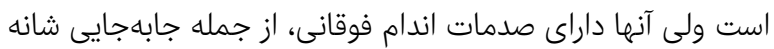

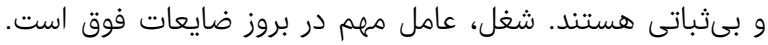

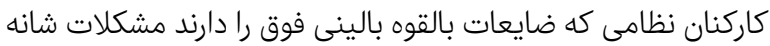

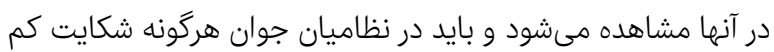

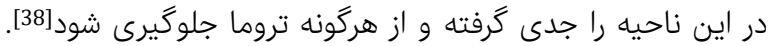


كه هزينههاى مالى آنها بسيار زياد است كه سالانه بالغ بر بميلياريارد

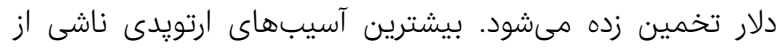

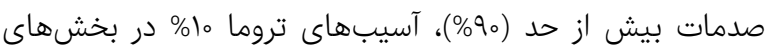

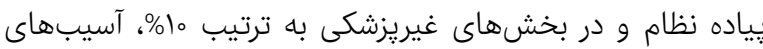

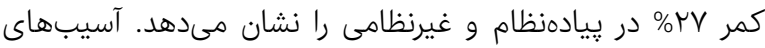

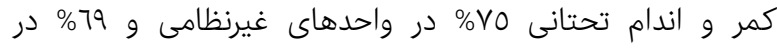

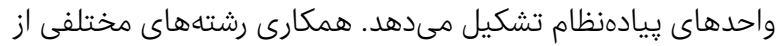

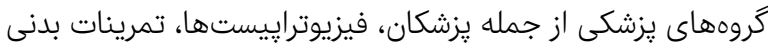

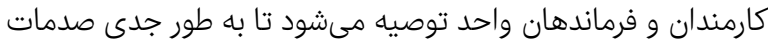

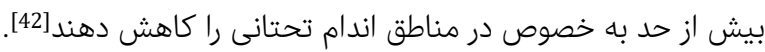

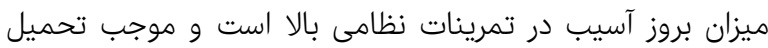

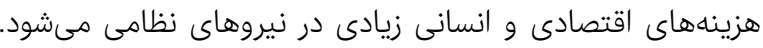

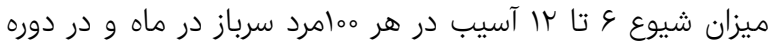

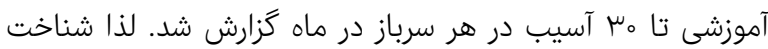

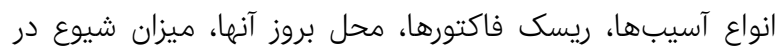

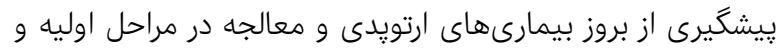

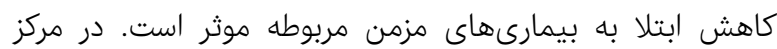

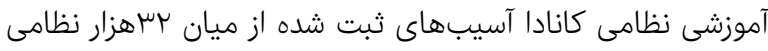

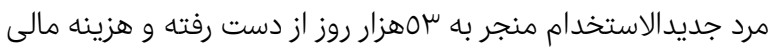

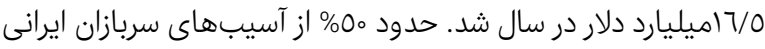

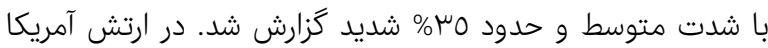

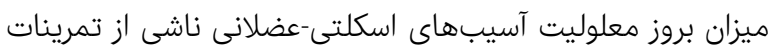

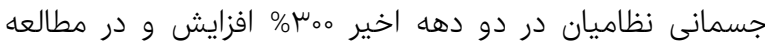

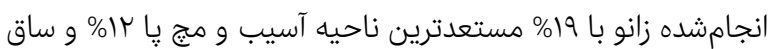

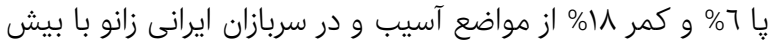
از

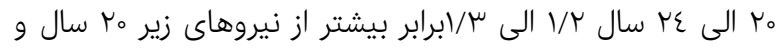

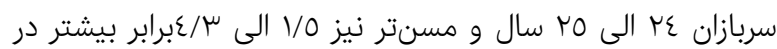

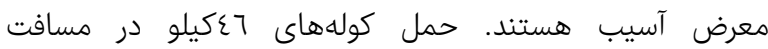

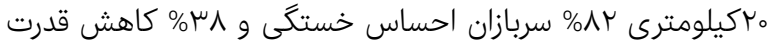

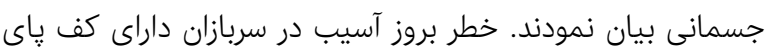

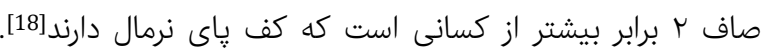
اقدامات موثر در بيشكَيرى از آسيبهاى اسكلتى-عضلانى نظاميان استران

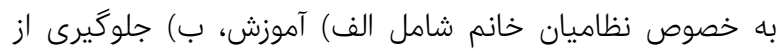

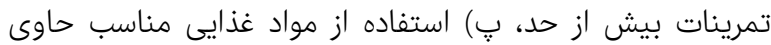

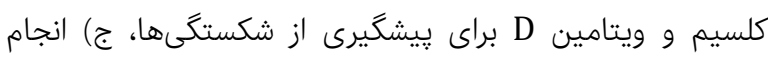

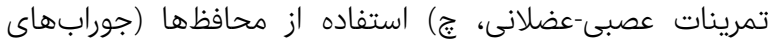

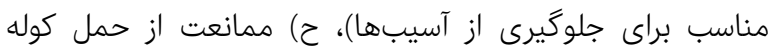

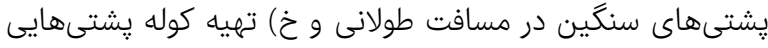

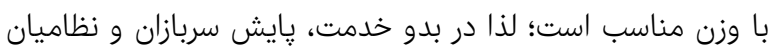

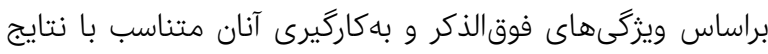

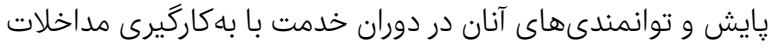
يِيشكيرانه در كاهش بروز آسيبهاي اسكلتى-عضلانى موثر خواهد بود [18].
صدمات ناشى از فعاليتهايى است كه در حين دركيرى با دشمن

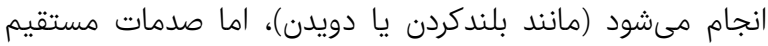

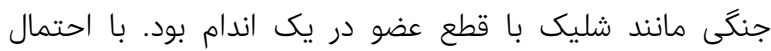

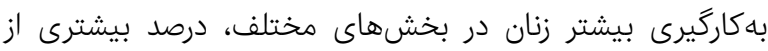
صدمات ناشى از مشاغل شغلى باشد [20].

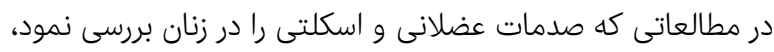

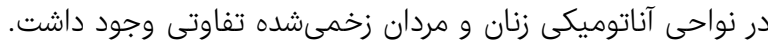

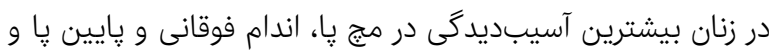

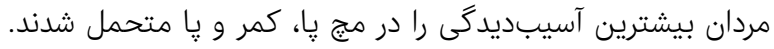

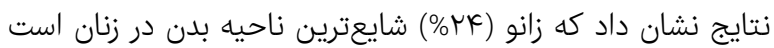

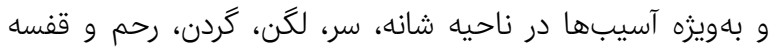

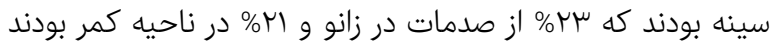
و در معرض استرسزاهاى فيزيكى متعددى از جمله فعاليتهاى

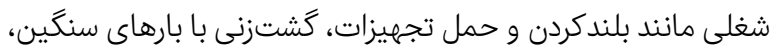

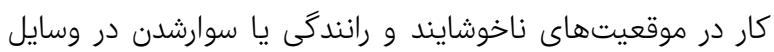

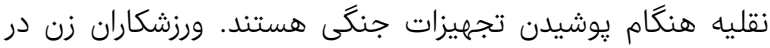

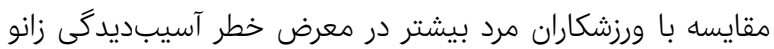

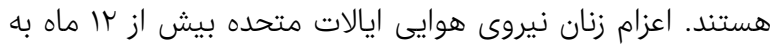

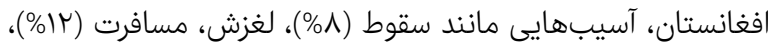

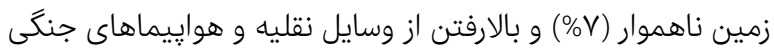

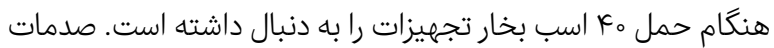

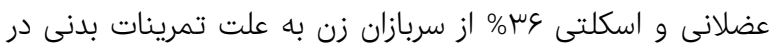

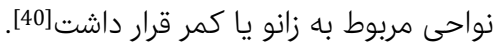
شيوع بورسيت سيتيك در نظاميان در مقايسه با غيرنظاميان بيشار بيشتر

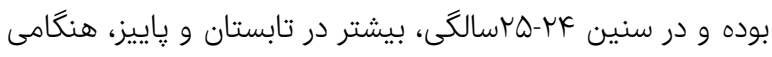

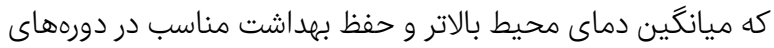

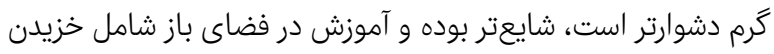

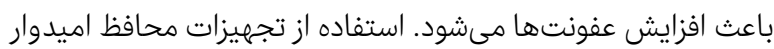

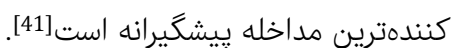
آسيبهاى اسكلتى-عضلانى يكى از مشكلات مهم در كاركنان ارتش

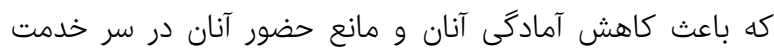

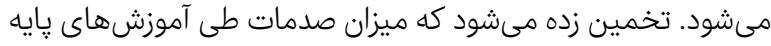

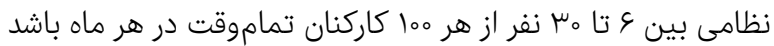

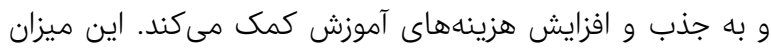

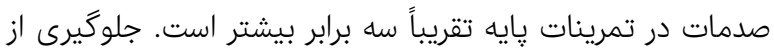

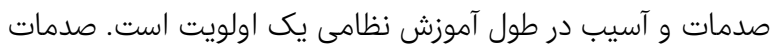

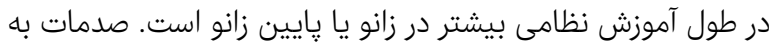
بافتهاى نرم در طبيعت متداول و بيشتر از حد استفاده از آن آن است.

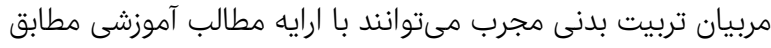

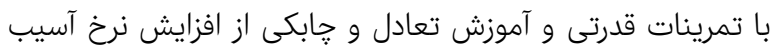

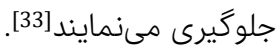

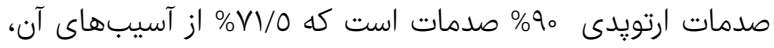

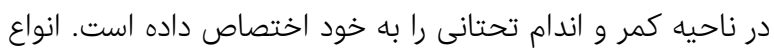
آسيبهاى ارتويدى در واحدهاى بيادمنظام و غيرنظاميان وجود دارد 
operation Iraqi Freedom by a US Army brigade combat team. J Trauma. 2010;68(1):204-10.

2- Sherrard J, Lenné M, Cassell E, Stokes M, Ozanne-Smith $\mathrm{J}$. Injury prevention during physical activity in the Australian Defence Force. J Sci Med Sport. 2004;7(1):10617.

3- Henderson NE, Knapik JJ, Shaffer SW, McKenzie TH, Schneider GM. Injuries and injury risk factors among men and women in US Army combat medic advanced individual training. Mil Med. 2000;165(9):647-52.

4- Kazemi M, Pieter W. Injuries at a Canadian national taekwondo championships: A prospective study. BMC Musculoskelet Disord. 2004;5(1):22.

5- Billings CE. Epidemiology of injuries and illnesses during the United States air force academy 2002 basic cadet training program: Documenting the need for prevention. Mil Med. 2004;169(8):664-70.

6- Pollock ML, Gettman LR, Milesis CA, Bah MD, Durstine L, Johnson RB. Effects of frequency and duration of training on attrition and incidence of injury. Med Sci Sports. 1977;9(1):31-6.

7- Nakanishi K, Ohrui N, Nakata Y, Hanada R, Kobayashi M, Ohashi K. Long-term disability among aviators in Japan air self-defense force: Analysis of 260 cases. Aviat Space Environ Med. 2003;74(9):966-9.

8- Ervin MD. Air force special operations command special operations surgical team (SOST) CONOPS. J Spec Op Med. 2008;8:68-75.

9- World Health Organization. International statistical classification of diseases and related health problems. Geneva: World Health Organization; 2004.

10- Karunanayake AL, Pathmeswaran A, Kasturiratne A, Wijeyaratne LS. Risk factors for chronic low back pain in a sample of suburban Sri Lankan adult males. Int J Rheum Dis. 2013;16(2):203-10.

11- Rayapati DK, Mallya KP, Prashanth N, Raghuveer H, Shobha E, Rangan V, et al. Effect of nicotine on bone healing in rats-A histological study. US Natl Libr Med Enlisted J. 2014;7(2):169-74.

12- Shier D, Butler J, Lewis R. Hole's essentials of human anatomy \& physiology. $12^{\text {th }}$ Edition. New York: McGrawHill Education; 2014

13- Yagi S, Muneta T, Sekiya I. Incidence and risk factors for medial tibial stress syndrome and tibial stress fracture in high school runners. Knee Surg Sports Traumatol Arthrosc. 2013;21(3):556-63.

14- Murley GS, Landorf KB, Menz HB, Bird AR. Effect of foot posture, foot orthoses and footwear on lower limb muscle activity during walking and running: A systematic review. Gait Posture. 2009;29(2):172-87.

15- Wolfe JA, Christensen DL, Mauntel TC, Owens BD, LeClere LE, Dickens JF. A history of shoulder instability in the military: where we have been and what we have learned. Mil Med. 2018;183(5-6):e158-65.

16- Belmont Jr PJ, Goodman GP, Waterman B, DeZee K, Burks R, Owens BD. Disease and nonbattle injuries sustained by a US army brigade combat team during operation Iraqi freedom. Mil Med. 2010;175(7):469-76.

17- Halvarsson A, Hagman I, Tegern M, Broman L, Larsson H. Self-reported musculoskeletal complaints and injuries and exposure of physical workload in Swedish soldiers serving in Afghanistan. PLoS One. 2018;13(4):e0195548. 18- Zarei M, Rahemi M. Military physical training-related injuries: A review of epidemiology and risk factor and prevention strategy studies. Ebnesina. 2015;17(2):52-64. [Persian]
با توجه به اينكه عوامل سازمانى-نظامى از اركان قابل كنترل مديريت

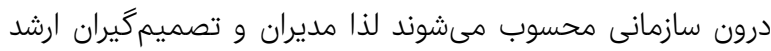

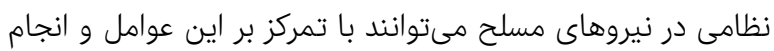

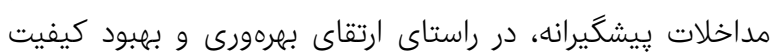

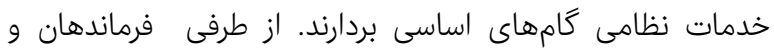

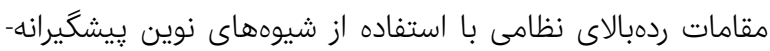

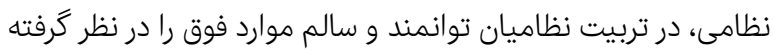
و تاثير بسزايى داشته باشند. نكات بالينى كاربردى براى جوامع نظامى: - شايعترين محل آسيب نظاميان، اندام تحتانى است.

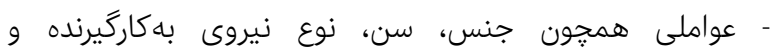

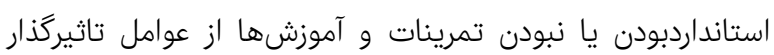
آسيبها در نظاميان است.

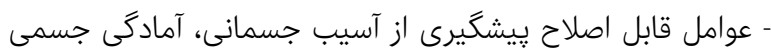
و رزيم غذايى مناسب است. ي ״يشنهاد مىشود كه آمادگى جسمانى سربازان با برگزارى تمرينات

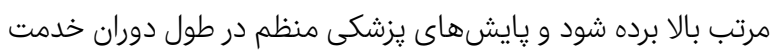

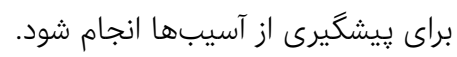

آلتيجه زآيرى تشكر و قدردانى: موردى از سوى نويسندگًان گزارش نشده است.

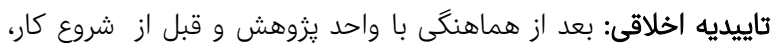

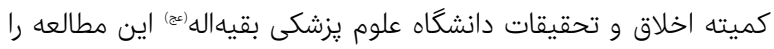
با كد IR.BMSU.REC.1399.36 مورد تاييد قرار داد. تعارض منافع: بدين وسيله نويسندكان تصريح مىنمايند كه هيج گُونه

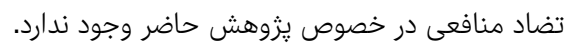

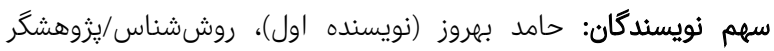

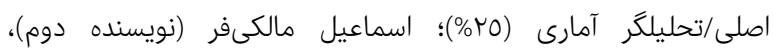

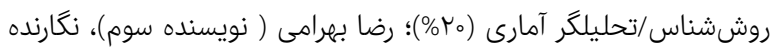

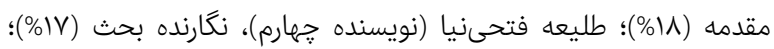

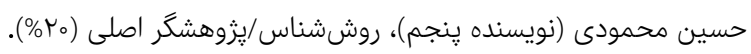

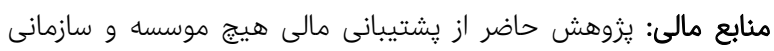

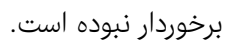

\section{منابع}

1- Belmont Jr PJ, Goodman GP, Zacchilli M, Posner M, Evans C, Owens BD. Incidence and epidemiology of combat injuries sustained during "the surge" portion of 
آسيبهاى عضلانى-اسكلتى رايج در نظاميان: يك مرور نظاممند ه.r

31- Lopes TJA, Simic M, Bunn PdS, Terra BdS, Alves DdS, Ribeiro FM, et al. Prevalence of musculoskeletal symptoms among brazilian merchant navy cadets: Differences between sexes and school years. Mil Med. 2017;182(11-12):e1967-72.

32- Nye NS, Pawlak MT, Webber BJ, Tchandja JN, Milner MR. Description and rate of musculoskeletal injuries in air force basic military trainees, 2012-2014. J Athl Train. 2016;51(11):858-65.

33- Schram B, Pope R, Orr R. Injuries in Australian army full-time and part-time personnel undertaking basic training. BMC Musculoskelet Disord. 2019;20(1):6

34- Synovec J, Shaw KA, Antosh IJ, Grassbaugh J, Tucker CJ, Parada SA, et al. Current practices in anterior cruciate ligament reconstruction in the US military: A survey of the society of military orthopaedic surgeons. Mil Med. 2018;184(1-2):e249-55.

35- Taanila H, Suni J, Pihlajamäki H, Mattila VM, Ohrankämmen 0, Vuorinen $\mathrm{P}$, et al. Aetiology and risk factors of musculoskeletal disorders in physically active conscripts: A follow-up study in the finnish defence forces. BMC Musculoskelet Disord. 2010;11(1):146.

36- Ashnagar M, Mohammadi Z, Sartang AG. Relationship between body mass index and musculoskeletal disorders and general health in military personnel. J Police Med. 2017;6(2):127-33. [Persian]

37- Ghaderi M, Semsar B, Ahmadzadeh J, Mohebbi I. Musculoskeletal disorders related to physical activities of the military training course and a preventive ergonomic solution: Review study. J Mil Med. 2017;19(4):317-25. [Persian]

38- Kampa R, Clasper J. Incidence of SLAP lesions in a military population. J R Army Med Corps. 2005;151(3):171-5.

39- Horoho P. Soldier 2020: Injury rates/attrition rates working group [Internet]. Unknown City: Army Medical; 2015 [Cited 2020 Jun 01]. Available from: https://cutt.ly/5hQv20o

40- Roy TC, Piva SR, Christiansen BC, Lesher JD, Doyle PM, Waring RM, et al. Description of Musculoskeletal Injuries Occurring in Female Soldiers Deployed to Afghanistan. Mil Med. 2015;180(3):269-75.

41- Schermann H, Karakis I, Dolkart O, Maman E, Kadar A, Chechik O. Olecranon bursitis in a military population: epidemiology and evidence for prolonged morbidity in combat recruits. Mil Med. 2017;182(9-10):e1976-80.

42- Schwartz O, Libenson T, Astman N, Haim L. Attrition due to orthopedic reasons during combat training: rates, types of injuries, and comparison between infantry and noninfantry units. Mil Med. 2014;179(8):897-900.
19- Amako M, Sasao H, Matsuhashi Y, Yato Y, Yoshihara Y, Arino $\mathrm{H}$, et al. Incidence and characteristics of traumatic shoulder instability in japanese military cadets. Mil Med. 2016;181(6):577-81.

20- Roy TC, Ritland BM, Sharp MA. A description of injuries in men and women while serving in Afghanistan. Mil Med. 2015;180(2):126-31.

21- Daniels CM, Dworak TC, Anderson AB, Brelin AM, Nesti LJ, McKay PL, et al. Gender disparities within US army orthopedic surgery: A preliminary report. Mil Med. 2017;183(1-2):e162-6.

22- Glad D, Skillgate E, Holm LW. The occurrence and severity of musculoskeletal disorders in Swedish military personnel during peacekeeping operations in Afghanistan. Eur Spine J. 2012;21(4):739-44.

23- Gun B, Dean R, Go B, Richardson C, Waterman BR. Non-modifiable risk factors associated with sternoclavicular joint dislocations in the US military. Mil Med. 2018;183(5-6):e188-93.

24- Hamstra-Wright KL, Bliven KCH, Bay C. Risk factors for medial tibial stress syndrome in physically active individuals such as runners and military personnel: A systematic review and meta-analysis. Br J Sports Med. 2015;49(6):362-9.

25- Hughes JM, Foulis SA, Taylor KM, Guerriere KI, Walker LA, Hand AF, et al. A prospective field study of U.S. Army trainees to identify the physiological bases and key factors influencing musculoskeletal injuries: A study protocol. BMC Musculoskelet Disord. 2019;20(1):282.

26- Molloy JM, Pendergrass TL, Lee IE, Chervak MC, Hauret KG, Rhon DI. Musculoskeletal injuries and United States army readiness part I: Overview of injuries and their strategic impact. Mil Med. 2020;185(9-10):e146171.

27- Enad JG, Headrick JD. Orthopedic injuries in US casualties treated on a hospital ship during operation Iraqi freedom. Mil Med. 2008;173(10):1008-13.

28- Flint JH, Pickett A, Owens BD, Svoboda SJ, Peck KY, Cameron KL, et al. Recurrent shoulder instability in a young, active, military population and its professional implications. Sports Health. 2018;10(1):54-9.

29- Hsiao MS, Cameron KL, Huh J, Hsu JR, Benigni M, Whitener JC, et al. Clavicle fractures in the United States military: Incidence and characteristics. Mil Med. 2012;177(8):970-4.

30- Alidoust Ghahfarrokhi E, Khodayi Estiyar V, Jalali Farahani M, Teknik K. The comparison of functional injuries of upper limbs, quality of life and general health between athlete and non-athlete martials. J Mil Med. 2013;15(2):111-6. [Persian] 